\title{
ORAL HISTORY, REMEMBERING PRACTICES AND THE PROBLEM OF “ACCESS” TO THE TRAUMATIC EXPERIENCE ${ }^{1}$
}

\author{
Natalia A. Artemenko (a) \\ (a) St Petersburg State University / Herzen State Pedagogical University of Russia / Research Center for \\ Cultural Exclusion and Frontier Zones, Sociological Institute, RAS. St Petersburg, Russia. \\ Email: n.a.artemenko[at]gmail.com
}

\begin{abstract}
The method of "oral history" is quite widely used today, despite the fact that it came into being not so long ago. The origins of the method of oral history should be sought for in the studies related to interviewing, and with reference to related disciplines, i.e. sociology, ethnology, political science and, partly, linguistics. Quite soon, the disputes over the relation of oral history and historical memory became common for critical literature. The interview method is a very complex way, which requires quite an effort, as well as the awareness of researcher's subjectivity of a high degree, therefore, some historians sees oral history as a highly unreliable source. Yet, it is impossible to ignore the fact that the method of oral history is in high demand in cases of no other sources except for the evidence of human memory being left. Oral history enables us to study not so much the facts of the past as the very human consciousness and its alteration, transformation, enables us to pose a question on the memory practices from a new perspective. Memory and remembering practices are closely related to oblivion, which, in its turn, indicates the need to eliminate the information that ravages the human psyche and the structure of public consciousness. Oblivion could be entitled "memory trauma" which should be understood as the events, destructive both to personal and social (including national) identity. Consequently the memory starts to be associated with the concept of trauma. The article delves into the relation between oral history and human memory, the problem of "accessing" the traumatic experience, special aspects of narrative in the traumatic experience.
\end{abstract}

\section{Keywords}

oral history; memory studies; memory; Modern; narrative; time regime; trauma; traumatic experience

This work is licensed under a $\underline{\text { Creative Commons «Attribution» } 4.0 \text { International }}$ License

1 The article summarizes the results of research, including those partially published in two articles (in Russian): Artemenko, N. (2018). Time, Memory, Trauma: Between Being and Nonbeing. Studia Culturae, 36(2), 124-136; Artemenko, N. (2019). Oral History and the Problem of "Access" to Traumatic Experience. Studia Culturae. 40(2), 128-138. 


\title{
УСТНАЯ ИСТОРИЯ, ПРАКТИКИ ПАМЯТСТВОВАНИЯ И ПРОБЛЕМА «ДОСТУПА» К ТРАВМАТИЧЕСКОМУ ОПЫТУ
}

\begin{abstract}
Артеменко Наталья Андреевна (a)
(а) Санкт-Петербургский государственный университет / Российский государственный педагогический университет им. Герцена / ЦИЗКОП СИ РАН. Санкт-Петербург, Россия. Email: n.a.artemenko[at]gmail.com
\end{abstract}

\begin{abstract}
Аннотация
Термин «устная история» ныне используется довольно широко, хотя возник он относительно недавно. Начало метода устной истории следует искать в исследованиях, касающихся интервьюирования, и в связи со смежными дисциплинами: социологией, этнологией, политологией, отчасти с лингвистикой. Довольно быстро общим местом в критической литературе стало обсуждение связи устной истории и исторической памяти. Метод интервью является очень сложным путём, требующим больших усилий, осознания высокой степени субъективности исследователя, поэтому устная история некоторыми историками считается весьма ненадежным источником. При этом нельзя не учитывать тот факт, что метод устной истории оказывается весьма востребованным там, где не осталось больше никаких источников, кроме свидетельств человеческой памяти. Устная история позволяет изучать не столько фактическую сторону прошлого, сколько само человеческое сознание и его изменение, его трансформацию, позволяет по-новому поставить вопрос о практиках памяти. Память и практики памятствования тесно связаны с забвением, которое в свою очередь указывает на потребность устранения той информации, которая обладает деструктивным воздействием на психику человека и структуры общественного сознания. Забвение можно было бы назвать «травмой памяти», понимая под этим те события, которые имеют деструктивное значение как для личной, так и социальной (в том числе и национальной) идентичности. Так память начинает связываться с понятием травмы. В статье рассматривается связь устной истории и человеческой памяти, проблема «доступа» к травматическому опыту, особенности нарратива при травматическом опыте.
\end{abstract}

\section{Ключевые слова}

устная история; практики памятствования; травма; травматический опыт; память; нарратив; временной модус; Модерн

Это произведение доступно по лицензии Creative Commons «Attribution» («Атрибуция») 4.0 Всемирная 
"But what if there will be no-one left besides them?"

"Besides whom?"

"Besides the people you want to forget."

"Parisienne" (a film directed by A. Sobolev, 2019)

\section{ORAL HISTORY. THE PROBLEM OF THE METHOD}

The method of "oral history" is quite widely used today, despite the fact that it came into being not so long ago. This concept was introduced to the global scientific practice as well as to Russian historiography in the late $20^{\text {th }}$ century. E. A. Rostovtsev in his The Russian Science on Oral History noted that,

... nowadays, oral history is not just a fashionable trend, but an entire industry of historical studies. Celebrated American and European scientists (historians, sociologists, psychologists) of the late $20^{\text {th }}$ century (J. Evans, A. Portelli, A. Haley, J. Vansina, P. Thompson, D. Bertaux, L. Niethammer, L. Passerini and many others) strived to define the problems of Oral History, develop of research instruments, form the basis for institutionalization of this realm with its own research centers, journals, training courses. It is impossible to object the fact that the development and popularization of oral history experienced the direct impact of the intensive advancements in technology used for recording and storing oral sources, forming of digital data banks and elaboration of methods applied for their analysis. However, the main reason for the rapid growth of this scientific field certainly reside in a fact that historiography of the $20^{\text {th }}$ and $21^{\text {st }}$ centuries not only avoided the thesis of $\mathrm{Ch}$. Langlois and Ch. Seignobos, implying that history is 'written' according to documents, but also resolutely revised its object of studies, i.e. the facts were replaced with a human being in all his manifestations. Without oral history it is apparently impossible to study the mentality of the dim and distant past of Europe (specifically, human psychology of the Middle Ages without resorting to folklore) or the history of African peoples used to remain the oral society up to the $20^{\text {th }}$ century, or, for instance, the everyday life of the elapsed $20^{\text {th }}$ century (Rostovtsev, 2018, pp. 523-524).

The origin of the method of oral history should be sought for in the studies related to interviewing, and with reference to related disciplines, i.e. sociology, ethnology, political science and, partly, linguistics. All this gave an impulse resulting in an appeal to the personality, a desire to individualize the masses. Quite soon the disputes over the relation of oral history and historical memory became common for critical literature. Indeed, both memory studies and oral history, as the research areas, are of interdisciplinary nature and besides historians, they give room for sociologists, psychologists, linguists, and philosophers, since oral history involves development of the methodology for in-depth interviews, critical analysis of 
their materials, detection of respondents' "traumatic" memories, etc. There is a great number of research literature on the issue of human ability to remember the long gone events, but it does not help to resolve a number of important contradictions, concerning understanding of memory, interactions of collective and individual memory, narrativization of memory, its "life" within a particular language, a discourse that is always socially conditioned, etc.

Lutz Niethammer, a prominent German historian, noted, focusing on the problem of memory, that

\begin{abstract}
most people are sure that memory is an automatic storage device and that the accumulated information must line up with reality, if, however, it doesn't, it considered nonsense and lies. Yet, memory works in a different way. The things a human memorizes are conditioned by some situation, thus, the most of what we perceive we forget. For instance, we forget that [...] which did not surprise us, did not capture us and we remember the information which has some novelty, situations that we were not ready for, which means much to us emotionally (for instance, pain or experiences of happiness). [...] In other words, everyone remembers his first kiss, but no one can remember all the kisses that he has been having ever since. Memory does not reproduce the past reality, but only something that caused an emotional outburst (Niethammer, 2014).
\end{abstract}

L. Niethammer addressed the issue of memory for a good reason, i.e. if oral history is, so to speak, "history from below," implying the methods attached to the individual, to his "Self," it is a way of recording, preserving and processing the unique memories of people whose memories would be lost otherwise, it also raises at least three questions. The first one (1) is about the way of translating the information about the past by the individual that, according to L. Niethammer, is always conditioned by the context, in other words, "the factors of collective memory in the case at hand are especially important, much more important than the individual memory, since collective memory rigidly censors the individual one," (Niethammer, 2014). The second one (2) is about the way of processing huge volumes of unstructured speech genres, which, in theory, should exclude any interpretation. And, finally, the last question, (3), to top it all, is about the subjectivity of an interviewer, since an interviewer himself may not be free from the generational, sexual or gender experience, or from the burden of higher education-all these things certainly affect questions, which guide a course of an interview, set a specific context and a keynote, and here it is difficult to pretend that "the subjectivity of people exists, but the one of researcher's doesn't not." 


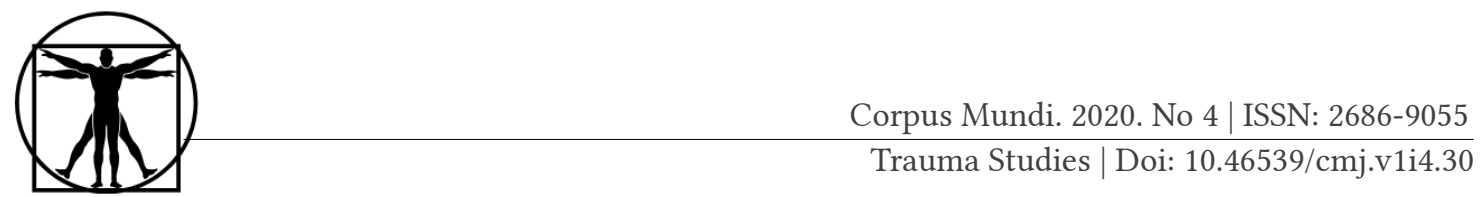

Therefore, the interview method is a very complex way, which requires quite an effort, as wee as the awareness of researcher's subjectivity of a high degree, therefore, some historians sees oral history as a highly unreliable source. As L. Niethammer recalled,

Personally, I associated these methods with rosy expectations of the mass subject being included into historical discourse. These novelties made their way through Western Europe and not only. The young scientists of those days actively used the new method, the same applied to sociology [...] and to related disciplines. Such populism, on the one hand, very soon led to the active spread of such line of activity, the former minority gained voice, access to the media, but on the other hand, it caused a good number of scientific disappointments (Niethammer, 2014).

Indeed, applying the methods of oral history, we gain an opportunity to collect the impressions and experiences of ordinary, so to speak, "makers of history" and, thereby, to take a step towards a more complete, if anything, to more adequate knowledge of the past. Oral history seeks to gather testimonies of contemporaries, and it is of the particular importance for the eras which, for one reason or another, were closed for studies or were studied with intentional reference to fabricated sources with, for instance, an ideological overtone.

The method of oral history is also in high demand in cases of no other sources except for the evidence of human memory being left. It should be noted that, hence, oral history enables us to study not so much the facts of the past as the very human consciousness and its alteration, transformation, which is also embodied in various historical events. As a multidisciplinary study, oral history provides essential material for anthropology, microhistory, history of mentalities, history of everyday life, historical psychology and other socio-anthropological areas.

Yet, as it was quite rightly noted by many historians, despite the fact that oral history is able to provide essential material which exhibits the subjective world of humans not only as a result of history, but also as a participant in history, nevertheless, it is still necessary to make allowance for a number of specific methodological aspects of such study. In the first instance, as it was previously noted, it applies to high-degree subjectivity of the materials obtained by the interview method. A narrator not only recalls the past, he inevitably re-experiences it all over again. Human memory is of plastic nature, it is limited by involuntary losses (forgetting), and fruits of its labor can be expressed in an alterable manner, being subjected to conscious, volitional influence (falsehood, distortion, reservation, etc.). Narration allows a narrator to make a new version of history, modeling his past in accordance with various political and cultural attitudes, 
special aspects of his biography and his psychological attitude. Herein, it is important to bear in mind that an author of memories is capable of altering his attitude towards the events. On the other hand, as it was also pointed out by L. Niethammer in his Questions to German Memory, an ability of a human to recollect can be supported and expanded by clarifying questions, providing him with information from other sources and showing him a contradiction between his words and this information, or the one between different parts of his statements. As it was noted by $\mathrm{Ni}$ ethammer, "It means that there is still a zone of latent memories, exiting between active memory and the complete oblivion, that can be activated through information and interaction with the interlocutor" (Niethammer, 2012 , p. 21). It means that such interview needs to be arranged in a special way. Herein, there are several points that should be kept in mind. In the first instance, people engaged in conversations mostly belong to different socio-cultural groups, and each of them is endowed with specific vision, which largely determines a strategy of a conversation, with his own specific arsenal of methods of deception, which are used for luring or concealing the information in the course of a conversation, and with his own self-deception. Niethammer pointed out that a researcher is mostly deceived when he believes that he is in some way superior to his interviewee, and also that he is destined to help him in some way. However, a historian is incapable of providing any services of the therapeutic kind, he has neither the power nor the criteria to judge anyone. The most typical deception of respondents occurs due to personal relationship with an interviewer which very often develops in the cause of long interviews, which makes them forget that they are facing a person of scientific aim, representing cultural or other institutions, interested in using the information received from them (Niethammer, 2012, 21). Therefore, Niethammer came to conclusion that

oral history is effective primarily in the cases when a content of an interview contradicts that what is commonly assumed, thought and known about the time in question. It is the very transition from history to literature, literary rapture, learning new things about the past which is truly interesting. And it makes historians abandon the questions they have learned, which they, perhaps, have once adopted from sociologists and ask about something else. [...] Thus, they will become richer, will be able to look into other parts of society, compare the inconsistency of different experiences, will be able to free themselves from shallowness of the media offering the same old digested, processed, generational experience (Niethammer, 2014). 


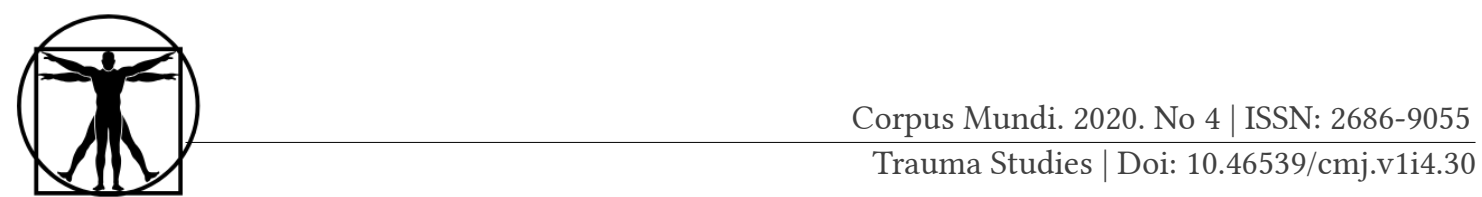

Yet, there is one more problem, i.e. a text narrated by a narrator must be somehow analyzed, it gets intensively processed by an interviewer, it is tempting to edit something when a record gets decoded, to correct both its semantics and grammar. In such case a researcher acts as a co-author of a text, and it largely reduces the historical value of a story. But this problem is far from being last. According to A. I. Filyushkin, a Russian historian,

\begin{abstract}
A researcher also faces a problem of the so-called 'matrix texts', i.e. a case when a respondent claims a standard, almost official text that he learned and now considers his own opinion as his real opinion, experience or personal testimony. The effect of such matrix texts can sometimes be simply amazing, i.e. researchers have proved that some of the memoirs revolving around the Russian Revolution or the Russian Civil War were actually based on films which appeared after these events (such as "Chapaev," "Lenin in October"). Yet, such substitution of personal impressions experienced by authors of the memories with some strange and improbable "matrix texts' occurred in their minds so long ago that a respondent is not always able to realize that he is simply translating a standpoint that was once imposed on him from the outside (Filyushkin, 2004, p. 6).
\end{abstract}

\title{
MEMORY $\leftrightarrow$ TRAUMA $\leftrightarrow$ NARRATIVE
}

We may say that due to its special relation to memory, "oral history" turns us to the very foundations and premises of history, demanding and, therewith, allowing us to reflect on the question of what are the relations between history and human beings, and how these relations have been shifting. We shouldn't forget that history as a form of human relations with the world was brought into being by human memory. But memory is of selective, plastic nature, there is forgetting, reservation, repression, both intentional and unconscious. We are not simply "animals capable of remembering," but beings, capable of forgetting both the good and the bad, the important and the unimportant. There is always a risk to involuntarily recall that what was long since forgotten, thus, the essential can become completely insignificant and the insignificant one suddenly becomes significant for us, it gets endowed with some special meaning, for instance, against the background of subsequent events. Such essential property of memory was indicated by Mikhail Rozhansky in his article entitled "'Oral History' - the Philosophy of Memory," i.e., "changing meaning of events that have long gone and reside only within, makes it possible to arrange events, people, words and gestures into sequential, cause-and-effect series, i.e. brings history as a form of life in to being [...] A human is incapable of controlling his memory, but he can't help striving to do so. His- 
tory turns into such instrument, the instrument for managing memory, the one which endues with sense, meaning and deprives of sense, meaning" (Rozhansky, 2014). We believe, that M. Rozhansky gave a very accurate definition for oral history calling it "the art of maintaining equilibrium between restoring the truth and the desire to awaken the 'stream of consciousness' in order to preserve it and reveal it to the world" (Rozhansky, 2014).

Such "art of maintaining equilibrium" implies that an interview of memories should hold some space for a respondent to grope for his memories and embody them into a form of his choice, with prioritizing and reservations, habitual to him. But what if the interview suddenly brings up memories of the traumatic experience which a person used to push to a fringe of his consciousness? And what if it is the project intentionally aimed at studying the specific traumatic experience? Then historicity of personal trauma turns into a topic of an interview, humiliation and danger to life, experienced by people, could often be so profound that many victims were able to return to independent life only by encapsulating this traumatic experience into an sealed capsule within their memory. Herein, we cannot accept the standpoint of L. Niethammer, posed the interview we have already quoted, i.e.

the psyche can suffer from [...] difficult memories. But it seems to me that the danger is too overestimated. The fact is that these people used to live with such psychological traumas for decades and almost no-one spoke about it, the issues were brought about only in the exceptional situations. [...] Generally, people have long since decided what they want to talk about and what they don't want to tell [...] here we should not underestimate an experienced researcher's ability to control himself [...] I would advise [...] not to consider trauma as some kind of stigmas on these events" (Niethammer, 2014).

It seems to us that such attitude towards the traumatic experience doesn't give consideration to its aspects which are capable of affecting a story, which can largely adjust narrative up to its complete distortion, which reveal specific temporality of the traumatic experience, making assessing it not only difficult, but sometimes even impossible. We also should not neglect the main intention of modern culture, i.e. denial of pain, destruction of pain due to its excessiveness, which fell on the $20^{\text {th }}$ century. Morris entitled contemporary culture as the "anesthetic" one.

Cathy Caruth, in her article entitled "Trauma, Time, History" called attention to a number of pending questions central for the concept of trauma, "What kind of truth, besides the psychological one, does trauma try to express? What story does she witness, or rather, how does her ver- 


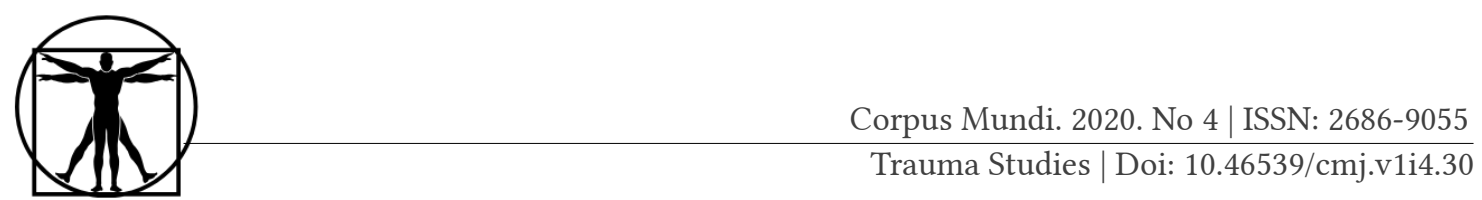

sion of a story differ from the memories of a more immediate form?" (Caruth, 2009, p. 561). Caruth contrasts traumatic memories to memories that refer to two memory levels which are most interesting in oral history (designated by L. Nithammer (Niethammer, 2012, pp. 29-30)) i.e. the active and latent ones. The level of active long-term memory keeps what is constantly needed and can be recollected effortlessly. In the first instance, it implies someone's vision of his life in total, a certain "set" of standard stories which are told on any occasion and which have already established themselves as communicative units. As it was once noted by A. MacIntyre, an American philosopher, "Each man in his actions, practices and fictions is essentially a story-telling animal" (MacIntyre, 2000, p. 277). Narrative always is complex interweaving of experiencing and a story-telling about it, the individual and collective experience, it is not a representation all the way through, but more often a construction, which doesn't diminish the epistemological value of narrative, since any construction is a representation of a different order, exhibiting the very mechanisms of constructing. MacIntyre noted that human identity, the unity of human history and the human "Self" is based on the unity of narrative organizing life into a single plot which has its introduction (beginning), climax (middle) and denouement (end). Individual narratives make the multiple histories of communities. "The Self inevitably discovers that his individual narrative has been already started by those who lived before him, and by that, which was before him," (Lekhtsier, 2018, p. 122) thus, narrative constitution of "the Self" is intersubjectively grounded. Yet, there is also internal dialectic within such narrative identity, i.e. a dialectic of constancy and variability, therefore, story-telling at the level of active memory is not always suitable for historical reconstruction, though it might contain interesting evidence of the narrator's processed experience and attitudes, remains of the models used for describing life situations adopted from culture.

A latent level of memory reveals memories that were once important for some reason: they can relate to routine things, actions, conditions that are repeated every day (and, strictly speaking, they do not possess a narrative structure and do not claim the status of semantic statement), yet, they may also refer to situations when the new experience is gained, which made a narrator face something, that he doesn't have an alreadyexistent categorical framework for. The latter kind of memories is of special plasticity, herein, narratives can multiply, enter into complex associative unities, disassemble and reassemble on some other grounds, and, since such memories lack connectivity, they usually represent a number of odd episodes. 
However, we can proceed by distinguishing one more level of memory, i.e. memory of the traumatic experience, which correlate to a latent level only to some extent. Trauma is the pain that "imprisons a person inside his body, disrupting intersubjective communications, since it remains untold, since there is no-one capable of sharing it" (Lekhtsier, 2018, p. 58). And although, the pain in such description given by Vitaly Lekhtsier was meant in medical since, it is also the best way to define the traumatic pain. C. Caruth called attention to the fact that memory under trauma works in a special way, we are rather dealing with a paradox, "... the one who survived against all odds, can hardly be described as the one who 'has memory'; those who survived catastrophic event are more likely to be experiencers of a story that does not quite belong to them" (Caruth, 2009 , p. 562) Trauma disrupts the integrity of biographical narrative, breaks open and overturns all methods of identity constitution, demands radical "reassembling" of a subject, which results in such traumatic experience that could be mastered and included as part of the narrative identity. Being a "lapse" of memory, its crucial failure, trauma offers the experience of becoming the Other, the experience implying radical transformation of subjectivity, which can be quite traumatic as such. "Making life go back to normal" becomes impossible, the traumatic experience that once came out of the shadows into the light demands to be included into biographical narrative, implanted into the outline of everyday storytelling. However, it does not happen since such kind of memories can exist only as "torn" narratives, chaotic stories. And if a level of everyday narratives implies that it is not an event that turns a story into a story, but a story turns an event into an event (Lekhtsier, 2018, p. 122), a case of a traumatic story doesn't imply any event which comes into being as something accomplished, possessing certain meaning and value. C. Caruth denoted that trauma has a specific time regime, i.e. since a traumatic "event" lacks immediacy of experiencing, it represents the very lapse of time,

... the trauma is conditioned not only by a threat to life, but by the fact that this threat, as such, was recognized by consciousness an instant later, than required. Therefore, the shock caused by the mind being confronted by a threat of death is not direct experiencing of a threat, but an absence of timely experiencing. Essentially, seeing something untimely the mind runs late with realizing. The very radical time gap between seeing and knowing holds the unbearable intensity of trauma. Therefore, trauma is a non-localizable event" (Caruth, 2009, p. 571-572).

What could be said in that respect about a subject of trauma? And what determination could we find for such subject? If we accept the classical definition, denoting the subject as the one that is whole and inde- 


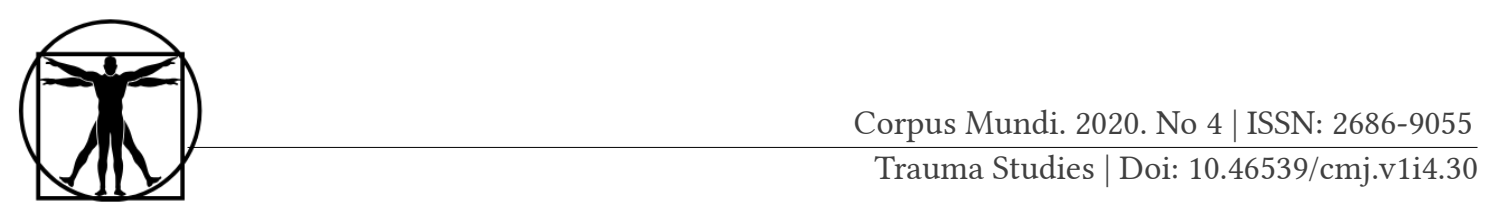

structible, then trauma is always a "hole" in conditional integrity of the subject, trauma is 'a wound of reality', or, rephrasing the words of Žižek, the one which creates a gap in narrative structures of memory. According to Cathy Caruth trauma should be attributed unambiguously neither to the past nor to the present, it represents a way of communication which the past carries on its existence trough.

\section{TIME REGIME OF MEMORY /TRAUMA}

There are certain concepts and terms an era adhere to and such adherence acts as a diagnosis of this era, a sign of time. Such concepts of our times, which is trying on both the end of an era, that is the $20^{\text {th }}$ century, and the beginning of a new century, are obviously represented by the concepts of "memory" and "trauma." These two concepts are deeply interlinked not just within the consciousness of historians, but also within the everyday consciousness of a man of today, which allows us to talk of memory "boom," that provokes focused attention to the past, to narratives about the past, to the ways of their foming, experiencing, sedimentating. Yet memory and remembering practices are closely related to oblivion, which, in its turn, indicates the need to eliminate the information that ravages the human psyche and the structure of public consciousness. Paul Connerton, a prominent English researcher of memory, built an entire typology of oblivion, and Paul Ricœur put oblivion into his triad of "memory-history- oblivion". Oblivion could be entitled "memory trauma," which should be understood as the events, destructive both to personal and social (including national) identity. Memory gets expressed, settles in narratives which the most traumatic events can get repressed in. Thus, memory starts to be associated with the concept of trauma. The latter concept, i.e. the concept of trauma, being adopted from the language of scientists to the language of mass media reporters, became so widespread that it forces us to look closely at the link between memory and a traumatic event or traumatic memories, at the time regime of trauma. Memory can no longer do without traumas. Moreover, the very organization of memory is trauma-based. Therewith, according to V. Mazin the paradox here lies in the fact that trauma does not fit in memory or, in the words of Lacan, persists not to fit in.

Attention focused on the concepts of memory "boom" and the time regime of trauma indicates that the old boundaries between the past, the present and the future have been erased. Aleida Assmann, a researcher of historical memory and memorial culture, noted that the Modern time regime has experienced major changes. Moreover, she suggests consid- 
ering it not as a catastrophe or crisis, but as "partial return to normality" (Assmann, 2017, p. 224). The structure of the Modern time regime demanded strict separation of the past, the present and the future, thus, it executed such separation. The alteration of this regime was caused by emerging new forms of resorting to the past. According to Assmann, hopes for the future have become more modest. The future has lost its irresistible appeal; it has ceased to be the very focal point for our aspirations and hopes. The level of violence exceeded in history of the 20th century has determined growing focusing on the past. Assmann wrote about "the unprecedented proportions of return of the past," which insists more and more on being treated responsibly, on remembering. Assmann quotes C. S. Mayer, an American historian, who claimed that the $20^{\text {th }}$ century ended between 1973 and 1984 and adds that it would be more correct to say that the $80 \mathrm{~s}$ witnessed not just the end of the $20^{\text {th }}$ century but the end of the dominance of the Modern time structure as well. Along with the Modern time regime with its clear separation of the past, the present and the future, we are also losing the mainstay. Assmann declared that "time is out of joint," putting this metaphor of being out of joint into the title of her book. What meaning does it have for us, living "after" the collapse of the Modern time regime? This primarily means that we lack clarity with respect to the interrelation of the past, the present and the future, to their intersections and separations. "The meaningfulness and orderliness of these time phases no longer seem natural and obvious to us" (Assmann, 2017, p. 213). "The past and the future have lost their inherent properties of sacredly revered objective authenticity, of something expected and being beyond our control; instead, the past and the future have turned nowadays into something which is produced in the present and in order to meet the needs of the present" (Assmann, 2017, p. 215). Assmann thinks that the crisis of the Modern time regime gives an opportunity for self-critical reflection, theoretical renewal, since the main thing here is that the present remains the very place where a man creates his own modernity, his own future and past. The theory of cultural memory, which springs from this temporal gap, proceeds from the inseparable interrelation of all three time phases i.e. the past, the present and the future. The interconnection of these three time phases and their involvement in the present get very literate description in the works of Russian semioticians Yuri Lotman and Boris Uspensky. Back in the late 70s they designate the close correlation of the categories of time, culture and memory, "Culture, allied to the past by memory, brings into being not only its future, but also its past, and in this sense, represents a mechanism of reacting against natural time" (Assmann, 2017, p. 220). Thus, there is no "past in itself," the 
extent of the past coming into being is determined by its focusing, thematizing, constructing and reconstructing done again and again by the present, which is the very time phase, the human perception, evaluation, comprehension occurs in. Therefore, the rejection of the past and obsession with the future, built into the Modern time regime, has been replaced by new forms of reactualization of the past. The new time regime increases the diversity of referring to the past. According to Assmann, it becomes more and more obvious that the past is not only a subject matter of history, but also an essential factor for life of society both in a political and private environment. A new interest in the past ceases to be solely the prerogative of history, all other interests in the past, whether they are individual or public, become legitimate. Revaluation of the past in the light of the current state of our knowledge and within the context of pending demands is becoming more and more obvious. Therewith, interests conditioned by historical events and traumatic experience begin to play an increasingly more important role.

Assmann delve into three new categories in her book, i.e. culture, identity and memory, focusing on the fact that from now on the mission of culture is to "establish that time frame which the present influences the future and preserves the past in the present or returns it to the present within. It's about the ability of culture to remember..." (Assmann, 2017, p. 232). Referring to Lotman and Uspensky, Assmann once again focuses on the fact that the concept of "culture as memory" should proceed from two propositions, i.e. 1 . The past does not disappear automatically 2 . The future and the past are getting constructed in the present. Memory of culture is built as a mechanism of generating and a mechanism of reproducing of culture itself. A construction of a cultural framework of time forms a clear contrast to physical time, yet it also counteracts individual obliviousness. Spontaneous individual memories cannot act as the mainstay of cultural heritage. This is how "collective identity" gets formed, i.e., according to Assmann, such self-image that is getting "constructed" by small or large social groups up to nations and states. A collective self-portrait gets created on the basis of collective narrative, key events, cultural artifacts and essential sites. Such interpretation of culture, which understanding was formed largely due to a change in the Modern time regime, as well as to an introduced concept of "collective identity," previously absent in a vocabulary of the modernization theory, results in a concept of memory also starting to gain a completely new meaning within the cultural paradigm.

This concept is comprised in such terms as "cultural memory," "collective memory," "historical memory," "memorial culture," and no longer 
refers to psychological processes occurring within an individual, but to a wide range of cultural practices aimed at preserving remains of the past, archiving, collecting. Yet, we are talking not so much about "culture of preservation" as about various forms of public referring to the past. Cultural memory is not some passive "accumulative" memory, it implies practices aimed at reactivation of the past, possibility of implementing both individual and collective development of history. It is the case of the past serving not so much as an archive, but as a parameter of the human experience, memories, issues of identity. Or, according to a quotation from J. $\mathrm{Ph}$. Reemtsma cited by Assmann, "... we use history to find out who we are and what we can hope for" (Assmann, 2017, p. 237). Thus, the past is no longer a place of automatic neutralization of emotions and erasing of experience, on the contrary, the past can no longer be separated from human experiencing and actions, from individual and collective suffering, including, or, may we say, concerning above all, those that were not framed by corresponding cultural narrative. Historical events which remained ignored for quite a long time and which have only recently started to get some attention can be referred to as "historical trauma," which D. Chakrabarty understands as "a combination of history and memory" (Assmann, 2017, p. 238). Assmann finds it is noteworthy that a concept of historical traumas originated not within historical science, but under influence of a multicultural practice of recognizing. Thus, we might see how fresh exploring of the past, made possible by changes in the time regime of our culture, led to new memorial practices, which, in their turn, opened the door for "interlinking" of history and memory, for understanding the past in terms of trauma or the traumatic past.

However, it took some time for memory and history to start adjoining each other within the same discourse. The discourse formed in the 90s implied contrasting "memory" with "history" as two irreconcilable oppositions. It is worth referring to Pierre Nora, a French historian, who stated that, "it not just righteous not to consider memory and history synonyms, but, furthermore, in many respects they can be denoting opposite phenomena. [...] The memory is generated by a group brought together by such memory. Therefore, as it was noted by Halbwachs, a number of memories equals a number of groups. Memory distinguishes one group from another. History, on the contrary, belongs to everyone, it is no-one's property and, therefore, it is of a universal nature" (Nora, 1996, p. 3). Yet, nowadays, as it is also noted by Assmann, the effort of enthusiasts of memorial culture makes more and more apparent the importance of linking presentations of the past and memory constructions to results of scientific studies. It is clear that in order to actualize the past, memorial 


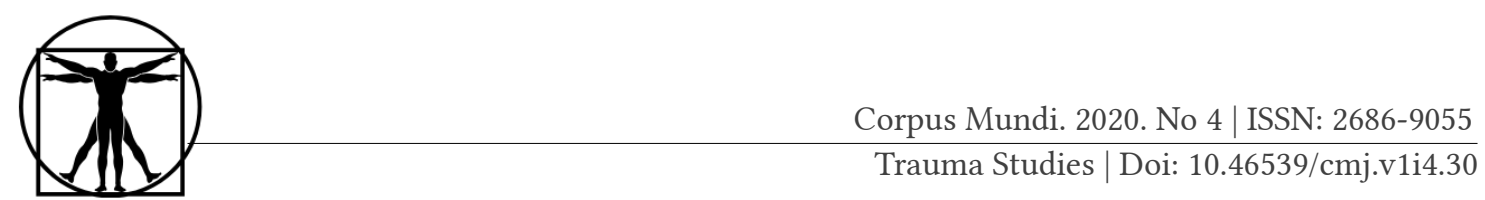

culture applies means and methods other than historical science, so Assmann poses the following formula, "Memorial culture is blind without historical science, and historical science is empty without interaction with memory" (Assmann, 2004, p. 246).

The peculiar memory "boom" that swept the $20^{\text {th }}$ century makes $\mathrm{P}$. Nora state that,

We live in the era of the worldwide triumph of memory. Over the previous twenty or twenty-five years, all countries, all social, ethnic, and family groups experienced a profound change in their traditional attitude to the past. Such change took diverse forms, i.e. critique of the officially recognized versions of history along with bringing the repressed elements of the historical process to the top; restoration of remains of the past which was destroyed or taken away; a cult of roots and elaboration of genealogical studies; rapid development of memorial events of all kinds; legal getting even with the past; growing number of various museums; increasing susceptibility to collecting archives and making them accessible; renewed attachment to that what is defined as 'heritage' in the English-speaking world, and as 'patrimoine' in France. Whatever is the combination such elements may appear in, the world is submerged by the surging wave of memories, firmly linking fidelity to the past, be it real or imaginary, to the sense of belonging, to collective consciousness and individual self-awareness, to memory and identity. [...] 'Memorial era', as I suggested terming movement of memory, is so all-embracing, deep and vigorous, that it is probably worth asking about its causes, even if we can name only the most general and obvious ones (Nora, 2005).

This question of causes asked by Pierre Nora was answered by Elena Trubina in her article, entitled "Learning to Remember: Vectors of Memory Study" in the following way,

One of the reasons memory keeps being attractive for studding is the close, paradoxical interweaving of cognitive and normative dimensions within this phenomenon. The question of what exactly cannot be forgotten in the vast and contradictory past of our shared world is associated, on the one hand, with a rational desire to learn from experience. On the other hand, it certainly also involves 'it should not be forgotten', i.e. appeal of historians, writers, public intellectuals, politicians, artists, teachers to the public, to one or another community. [...] Consideration given to the numerous manipulations which memory gets subjected to for the political benefit as well as the extent which alternative versions of the past are hushed up to, is one of the major work achievements in this realm (Trubina, 2011, p. 25). 


\section{PLURALISM OF MEMORY}

The transformation of the Modern time regime has caused changes in the attitude not just to the past, but also to that what the past demands from us i.e. to remembering. Historical memory, collective memory, cultural memory, those are the concepts which help historians, sociologists, culture experts, philosophers in their attempts to explain those new remembering regimes that started to take shape in new post-modern time coordinates. Therewith, Assmann noted that cultural memory "has ceased to be a private affair of every nation" (Assmann, 2011). The modern theory of memory is trying to figure out what makes memory work more than just an individual act. Individual and collective memories are becoming less sacred, more and more recognized as social and cultural constructs, acquiring their own history.

However, there is no direct path going from the individual experience and individual memories to collective memory. It is not a set of separate memories, but a historical reconstruction, assigning frames for individual memories, due to something that was experienced individually, was recognized by a subject in historical reconstruction or a subject ascribes reconstructed history to his own memories. According to A. Assman, "Collective memory allows community members to preserve value orientation and coordinate systems, overcoming spatial and temporal distances." (Assmann, 2016, p. 16).

Pierre Nora, who authored the concept of "sites of memory," said in respect of term of "collective memory" that,

Although history, which has become a scientific discipline, was built proceeding from memory, yet it was built against memory, which was considered individual, psychological, deceptive, no more than evidence in need of interpretation. History used to be an realm of the collective, when memory was a realm of the individual. History used to be single but memory used to be inherently plural, due to its individual essence. The idea of collective memory, emancipating and sacralized, turned this ratio upside down. Individuals used to have memory and as for communities, they used to have history. The idea that it is the very communities that possess memory presupposes a profound change in the place of individuals in society and their relation to the collective: here is the secret of a curious, explanationseeking success of another idea, namely the idea of identity. [...] The term of 'identity' experienced a semantic inversion similar and parallel to the one that occurred with the term of 'history.' It has turned from an individual concept into the collective one, from subjective, so to speak, into the logical and objective one. The identity traditionally defines the individual in his uniqueness, so that it even acquires predominantly administrative 
and police meaning. [...] Nowadays this word became a category of a group, a form of defining a man 'from the outside' (Nora, 2005).

According to P. Nora, memory is replacing history as a certain way of linking the past, the present and the future. Reading about "historical memory," "difficult memory," "memory policies," "memory conflicts," "memory drama," we find ourselves in a situation of modernity which treats memory both as a central issue and a framework for many social, political, cultural, artistic and suchlike practices. What makes "new memory" different from the traditional understanding (which certainly, is here to stay) of memory as a human capability of remaining the same in the changeable stream of life, referring to the past from the present, and coming back to the present from the past? "New memory" represents a form of existential, social and political action: it restores the experience that is at risk of deprivation; it also constructs and supports certain forms of shared experience in the present. Memory is performative, an act that does not describe a certain state of affairs, but creates it. It specifies or establishes the conditions something becomes memorable under, causes a certain affect of memories. Whereas, traditional memory is aimed at preserving continuity of the very subject of remembering, that remains "one and the same," new memory, on the contrary, comes into being as a response to experiencing of the impossibility for history to be directly continued, as it was understood in the great ideologies of Modern Times.

We might say that individual or collective memory, cultural memory and historical science represent different and independent approaches to the past, and each of them can't be reduced to the other one, which yields the pluralism of memory. As it was noted by Assmann, the simultaneous existence of different types of memory should not be considered "postmodern relativism" (Assmann, 2016, p. 22). We rather deal with a system of complementarities and mutual control and counterbalance. Yet, boundaries between different areas of memory are by no means impenetrable and often exhibit diverse intersections.

Therewith, we should understand that any memory is not impartial and it is determined by what gets selected into or excluded from it. Such selecting or excluding might represent either activity of the one (or the ones), who select or exclude, or passivity, in other words, repressing, which remains unrealized by those who participate in such selection. The latter one is more frequently regarded as a case of memory trauma, of various traumas, one way or another linked to different approaches to the past and different remembering practices. Anyhow, memory begins to play the role of theodicy (literally, "justification of God" that is, an expla- 
nation of how the goodness and wisdom of the creator is consistent with the existence of evil) for the world where theodicy is fundamentally impossible...

\section{ACKNOWLEDGEMENTS}

The research was supported by the Russian Foundation for Basic Research, project No. 18-011-00570 A "Theory of Cultural Injury: Individual Traumatic Experience and Experience of Historical Catastrophes".

\section{References}

Assmann, A. (2011). Memory Has Become the Frontier in the Game of Politics. An Interview of January 27, 2011. Retrieved from https://www.gazeta.ru/culture/ 2011/01/27/a_3 506234.shtml, last accessed on 15 April 2020. (In Russian).

Assmann, A. (2016). New Discontent with Memorial Culture. Moscow: New Literary Observer. (In Russian).

Assmann, A. (2017). Is Time out of Joint? On the Rise and Fall of the Modern Time Regime. Moscow: New Literary Observer. (In Russian).

Assmann, J. (1995). Collective Memory and Cultural Identity. New German Critique, (65), 125-133.

Assmann, J. (2004). Memory: Writing, Memory of the Past and Political Identity in the High Cultures of Antiquity. Moscow: LRC Publishers. (In Russian).

Caruth, C. (1996). Unclaimed Experience: Trauma, Narrative and History. Baltimore: Johns Hopkins University Press.

Caruth, C. (2009). Trauma, Time and History. In S. Ushakin \& E. Trubina (Eds.) Trauma Points: Collected Papers (pp. 561-581). Moscow: New Literary Observer (In Russian).

Filyushkin, A. (2004). Oral History. Research Guidelines. St Petersburg: Publishing House of St Petersburg Polytechnic University. (In Russian).

LaCapra, D. (1996). Representing the Holocaust: History, Theory, Trauma. NY: Cornell University Press.

Lekhtsier, V. (2018). Illness: Experience, Earrative, Hope. Essay on Social and Humanitarian Research in Medicine. Vilnius: Logvino literatūros namai. (In Russian).

MacIntyre, A. (2000). After Virtue: A Study in Moral Theory. Moscow: Academic Project, Yekaterinburg: Business Book. (In Russian).

Morris, D. B. (1993). The Culture of Pain. Berkley, Los Angeles, London: University of California Press.

Niethammer, L. (2012). Questions to German Memory. Articles on Oral History. Moscow: Novoe Izdatelstvo Publishing House. (In Russian).

Niethammer, L. (2014). Seminar Theoretical and Practical Aspects of Oral History with Lutz Niethammer, February 4, 2014. Retrieved from https://urokiistorii.ru/article/52 024._(In Russian). 


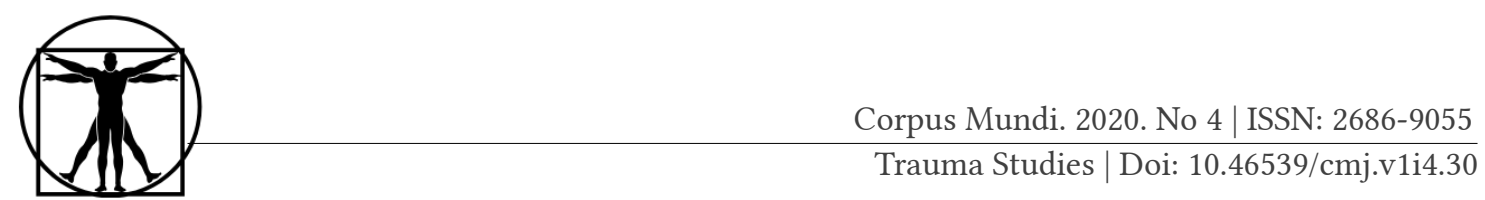

Nora, P. (1996). Realms of Memory: Rethinking the French Past. Volume 1. Conflicts and Divisions. New York, Chichester, West Surrey: Columbia University Press.

Nora, P. (2005). Global Triumph of Memory. Emergency Reserves, Vol. 2. Retrieved from https://magazines.gorky.media/nz/2005/2/vsemirnoe-torzhestvo-pamyati.html (In Russian).

Rostovtsev, E. (2018). The Russian Science on Oral History. Bulletin of Saint Petersburg University. History, 63(2), 523-524. (In Russian).

Rozhansky, M. (2014). "Oral History"-the Philosophy of Memory. Retrieved from http:// gefter.ru/archive/13 083 (In Russian).

Trubina, E. (2011). Learning to Remember: Vectors of Memory Studies. Power of Time: the Social Frames of Memory. Moscow: Variant Publishing House. (In Russian).

\section{Список литературы}

Assmann, J. (1995). Collective Memory and Cultural Identity. New German Critique, (65), 125-133.

Caruth, C. (1996). Unclaimed Experience: Trauma, Narrative and History. Baltimore: Johns Hopkins University Press.

LaCapra, D. (1996). Representing the Holocaust: History, Theory, Trauma. NY: Cornell University Press.

Morris, D. B. (1993). The Culture of Pain. Berkley, Los Angeles, London: University of California Press.

Nora, P. (1996). Realms of Memory: Rethinking the French Past. Volume 1. Conflicts and Divisions. New York, Chichester, West Surrey: Columbia University Press.

Ассман, А. (2011). Память стала передним краем в политической игре. Интервью 27 января 2011. Retrieved from http://www.gazeta.ru/culture/2011/01/27/ a_3506 234.html

Ассман, А. (2016). Новое недовольство мемориальной культурой. Москва: Новое литературное обозрение.

Ассман, А. (2017). Распалась связь времен? Взлет и падение темпорального режима Модерна. Москва: Новое литературное обозрение.

Ассман, Я. (2004). Культурная память. Письмо, память о прошлом и политическая идентичность в высоких культурах древности. Москва: Языки славянской культуры.

Карут, К. (2009). Травма, время, история. В Травма: пункты: Сборник статей. Москва: Новое литературное обозрение.

Лехциер В. Л. Болезнь: опыт, нарратив, надежда. Очерк социальных и гуманитарных исследований медицины. Вильнюс: Logvino literatūros namai, 2018

Макинтайр, А. (2000). После добродетели: Исследования теории морали. Москва: Академический Проект; Екатеринбург: Деловая книга.

Нитхаммер, Л. (2012). Вопросы к немецкой памяти. Статьи по устной истории. Москва: Новое издательство. 
Нитхаммер, Л. (2014). Семинар «Теоретические и практические аспекты устной истории». 4 февраля 2014. Retrieved from https://urokiistorii.ru/article/52 024

Нора, П. (2005). Всемирное торжество памяти. Неприкосновенньй запас, (2).

Retrieved from https://magazines.gorky.media/nz/2005/2/vsemirnoetorzhestvopamyati.html

Рожанский, М. А. (2014). «Устная история»- философия памяти. Retrieved from http://gefter.ru/archive/13083

Ростовцев, Е. А. (2018). Российская наука об устной истории. Вестник СанктПетербургского университета. История, 63(2), 523-524.

Филюшкин, А. И. (2004). Методические указания по проведению исследований по устной истории. Санкт-Петербург: Изд-во СПбГПУ. 